\title{
T-Cell Receptor-Associated Transmembrane Adapter 1
}

National Cancer Institute

\section{Source}

National Cancer Institute. T-Cell Receptor-Associated Transmembrane Adapter 1. NCI

Thesaurus. Code C30128.

T-cell receptor-associated transmembrane adapter 1 (186 aa, $21 \mathrm{kDa}$ ) is encoded by the human TRAT 1 gene. This protein is involved in the stabilization of the T-cell receptor/CD3 complex. 